\title{
STUDI LIVING HADIS TENTANG HAK DAN TANGGUNG JAWAB TUNGGU TUBANG PADA TRADISI MASYARAKAT SEMENDE
}

\author{
Uswatun Hasanah \\ Fakultas Ushuluddin dan Pemikiran Islam UIN Raden Fatah Palembang \\ uswatunhasanah1903@gmail.com
}

\begin{abstract}
On the rights and responsibilities as Tunggu Tubang at the same time with the tradition (sunnah) Rasulullah saw in general. As mentioned inside has been referred to as a man (husband) is a leader in finance and he will be asked about leadership, but in rights and responsibilities Wait Tubang associate with the woman in charge of it. This study uses vertical conformity between two traditions, namely tradition (sunnah) Rasulullah see and tradition of society in rights and responsibilities of Tunggu Tubang.
\end{abstract}

Keywords: rights, responsibilities, traditions (customs), traditions (sunnah of the Messenger of Allah).

\begin{abstract}
Abstrak : Pada hak dan tanggung jawab sebagai Tunggu Tubang selintas pandang seolah bertentangan dengan tradisi (sunnah) Rasulullah saw secara umum. Sebagaimana yang dijelaskan di dalam hadis bahwa seorang laki-laki (suami) adalah sebagai pemimpin dalam keluarganya dan ia akan ditanya tentang kepemimpinannya, namun dalam hak dan tanggung jawab Tunggu Tubang seolah wanita yang memiliki tanggung jawab tersebut. Penelitian ini mencoba menyoroti kesesuaian antara dua tradisi yaitu tradisi (sunnah) Rasulullah saw dan tradisi masyarakat Semende dalam hak dan tanggung jawab Tunggu Tubang.
\end{abstract}

Kata Kunci : hak, tanggung jawab, tradisi (adat), tradisi (sunnah Rasulullah saw). 


\section{A. Pendahuluan}

Setiap individu adalah pemimpin yang memiliki pengertian bahwa ia bertanggung jawab penuh akan apa yang dipimpinnya. ${ }^{1}$ Mulai dari tanggung jawabnya kepada dirinya sendiri sampai pada tanggung jawabnya terhadap lingkungan dan masyarakat di sekitarnya. Rasulullah saw bersabda

كلكم راع و كلكم مسؤل عن رعيته فا لاعملم راع وهو مسؤل عن رعيته و الرجل راع في اهله وهو مسؤل عن رعيته و المراة

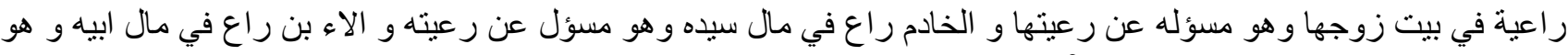
مسؤل عن رعيته فكلكم مسؤل عن رو رعبته

Sетиa kaтu adalah pemimpin dan semua kamu bertanggung jawab tentang apa yang dipimpinnya. Maka seorang Imam (Pemimpin) adalah sebagai penanggung jawab (yang akan ditanya) tentang kepemimpinannya. Seorang laki-laki (suami) adalah sebagai pemimpin dalam keluarganya dan ia akan ditanya tentang kepemimpinannya. Dan seorang wanita (istri adalah pemimpin di rumah suaminya yang ia akan ditanyakan tentang hasil pimpinannya. Seorang pembantu (asisten rumah tangga) adalah menjadi pemimpin dan mengawasi harta benda majikannya, dan ia bertanggung jawab dari apa yang dipimpinnya. Seorang anak adalah pengawas harta benda orangtuanya dan ia akan ditanyakan tentang hal pengawasannya. Maka kamu semua adalah pemimpin dan kamu semua akan ditanyakan tentang apa yang dipimpinnya.

Masyarakat sebagai suatu tempat berinteraksi antara seorang individu dengan individu lainnya, tidak sama dalam merespons ajaran Islam, khususnya yang berkaitan dengan hadits-hadits Rasulullah saw. Kondisi masyarakat saat menerima hadis sebelumnya telah memiliki tradisi, budaya dan aturan yang telah diyakini, dipedomani dan diterapkan dalam kehidupan. Dengan kondisi tersebut hadis yang datang ke dalam masyarakat membutuhkan penyesuaian dan fleksibelitas untuk dapat diterima dan menyatu di dalam kehidupan masyarakat. Pada akhirnya interaksi sunnah Rasulullah saw dan budaya masyarakat akan melahirkan satu bentuk baru dalam penerapan sunnah Rasulullah saw, yang tidak terkatagori bid'ah, sesat apalagi menyesatkan akan tetapi kolaborasi ini menjadi satu alternatif baru dalam menjalankan syari'at.

Dalam hal tanggung jawab sebagai Tunggu Tubang misalnya, tradisi yang melekat kuat pada masyarakat Semende ini, selintas pandang seolah bertentangan dengan tradisi (sunnah) Rasulullah saw secara umum. Sebagaimana yang dijelaskan di dalam hadis bahwa seorang laki-laki (suami) adalah sebagai pemimpin dalam keluarganya dan ia akan ditanya tentang kepemimpinannya, namun dalam hak dan tanggung jawab Tunggu Tubang seolah wanita yang memiliki tanggung jawab

\footnotetext{
${ }^{1}$ Syekh Muhammad al-Husaimi, SyarahRiyadhusShalihin, (Jakarta: DarulFalah, 2006), 11.

2 Abu Abd Allah Muhammad ibn Ismail ibn Ibrahim ibn al-Mughirahibn Bardizbah al-Bukhariy (selanjutnya disebut al-Bukhariy), al-Jami' al-Shahih al-Musnad al-Mukhtashar $m$ in Hadis Rasul Allah Shalla alaihi wa Salam (selanjutnya disebut Shahih al-Bukhariy), (Beirut: Dar al-Kutub al-Ilmiyyah, [t.th.]), 21.
} 
tersebut. Penelitian ini mencoba menyoroti kesesuaian antara dua tradisi yaitu tradisi (sunnah) Rasulullah saw dan tradisi masyarakat Semende dalam hak dan tanggung jawab Tunggu Tubang.

\section{A. Pembahasan.}

Tunggu Tubang adalah satu jabatan dalam struktur adat Semende yang biasanya dipegang oleh anak perempuan tertua dengan tugas menjaga dan mengurus harta pusaka keluarga (Jurai). ${ }^{3}$ Telah menjadi kesepakatan adat bahwa yang mengemban tugas sebagai Tunggu Tubang adalah anak perempuan sulung. Meskipun anak perempuan tersebut memiliki banyak kakak laki-laki bahkan meskipun ia merupakan anak terkecil di dalam keluarga serta merupakan anak perempuan satusatunya.

Adapun tanggung jawab Tunggu Tubang ${ }^{4}$ adalah sebagai berikut :

1. Menjaga dan mengurus harta pusaka.

2. Menjaga dan mengusus orang tua.

3. Menghormati Meraje dan mematuhi perintahnya.

4. Mematuhi dan menjalankan aturan adat.

Berikut akan dijelaskan tentang pelaksanaan tanggung jawab Tunggu Tubang tersebut satu persatu dan kesesuaiannya dengan ketentuan hadis tentang tanggung jawab tersebut.

1. Menjaga dan mengurus harta pusaka.

Menjaga dan mengurus harta pusaka merupakan tugas pokok Tunggu Tubang (anak perempuan sulung). Harta pusaka ini secara umum setidak-tidaknya terdiri dari sebuah rumah dan sebidang sawah. Berkaitan dengan tugas pokok Tunggu Tubang ini Rasulullah saw bersabda :

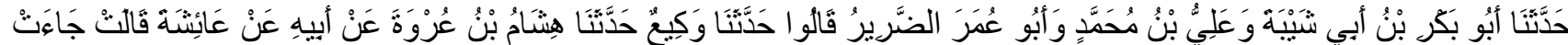

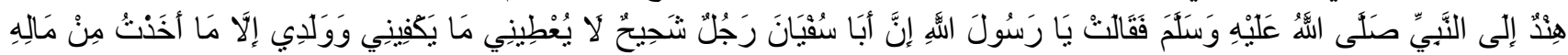

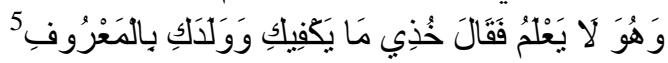

Telah menceritakan kepada kami Abu Bakr bin Abu Syaibah berkata, telah menceritakan kepada kami Ali bin Muhammad dan Abu Umar Aal-Dharir mereka berkata; telah menceritakan kepada kami Waki' berkata, telah menceritakan kepada kami Hisyam bin Urwah dari Bapaknya dari 'Aisyah ia berkata, "Hindun datang menemui Nabi shallallahu 'alaihi wasallam dan berkata, "Wahai

3 Syamsul Hak (Peniliti Kebudayaan pada Kantor Depdikbud Kecamatan Semendo di Pulau Panggung) sebagaimana dikutip oleh Dzulfikriddin, Kepemimpinan Meraje dalam Masyarakat Adat Semende dan Kesesuaiannya dengan Kepemimpinan dalam Islam (Palembang : Pustaka Auliya, 2001), 37.

4 Dzulfikriddin, Kepemimpinan Meraje dalam Masyarakat Adat Semende dan Kesesuaiannya dengan Kepemimpinan dalam Islam, 39-40. Bandingkan dengan Soerojo Wigjodinoe, Pengantar dan Azas-Azas Hukum Adat (Jakarta: Gunung Agung, 2000), 19. Bandingkan juga dengan Syekh Mahmud Syaltut, Akidah dan Syari'ah Islam, diterjemahkan oleh Fachruddin HS (Jakarta : Gunng Agung, 1998), 15.

${ }^{5}$ Mausuah al-Hadis al-Syarif al-Kutub al-Tis'ah, Shahih al-Bukhari : Kitab al-Syahadah no. 2464. 
Rasulullah, Abu Sufyan adalah seorang laki-laki yang pelit, ia tidak memberi nafkah yang bisa mencukupi aku dan anakku, kecuali dengan sesuatu yang aku ambil dari hartanya tanpa sepengetahuannya!" Beliau lantas bersabda: "Ambillah uang miliknya yang bisa mencukupi nafkahmu dan juga anakmu dengan ma'ruf.

Melalui asbab al-wurud hadis tersebut dipahami bahwa adanya perintah dari Rasulullah saw tentang sistem pengaturan keuangan dalam sebuah keluarga. Dari lafal ألَعْرُوفِ dan mengindikasikan adanya sebuah perintah untuk mengatur keuangan dengan menggunakan manajemen yang baik. Hindun sebagai sahabat wanita yang menerima perintah mengindikasikan bahwa seorang wanita (istri) adalah orang yang tepat sebagai pengatur keuangan dalam rumah tangga.

Tidak ada yang menyimpang dari apa yang diajarkan oleh hadis bahwa pengatur keuangan di rumah tangga adalah seorang perempuan. Meskipun beda dalam posisinya namun baik perempuan Tunggu Tubang maupun seorang istri, keduanya sama-sama merupakan perempuan terbesar dalam keluarga yang diharapkan mampu memimpin dan mengatur keuangan keluarga. Tanggung jawab yang diemban oleh Tunngu Tubang dalam pengelolaan harta pusaka bahkan jauh lebih besar dibandingkan seorang istri. Tidak hanya anak keturunan yang harus dipersiapkan masa depannya, tetapi Tunggu Tubang juga bertanggung jawab terhadap seluruh saudara kandungnya juga keturunan mereka.

Di balik tanggung jawab yang diberikan kepada Tunggu Tubang untuk menjaga dan mengurus harta pusaka adalah sebuah upaya untuk menjadikan orang tua berpikir dan berupaya agar meninggalkan harta yang cukup bagi anak keturunannya. Hali ini sejalan dengan sabda Rasulullah saw :

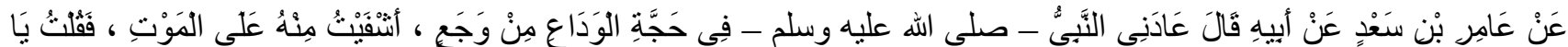

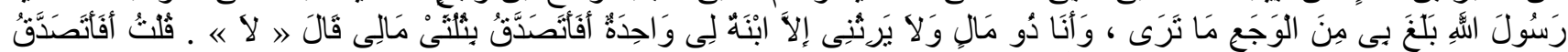

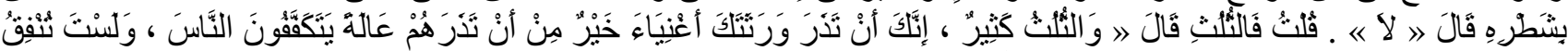

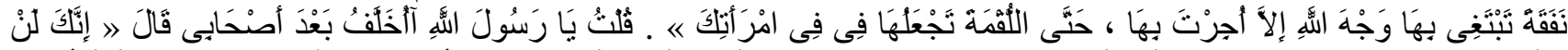

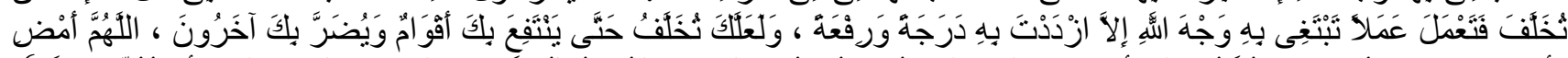

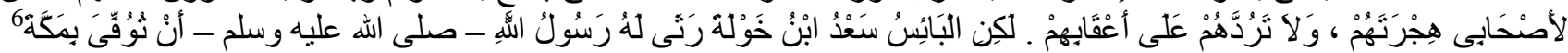

Dari 'Amir bin Sa'ad, dari ayahnya, Sa'ad, ia adalah salah seorang dari sepuluh orang yang dijamin masuk surga- berkata, Rasulullah shallallahu 'alaihi wa sallam menjengukku ketika haji Wada', karena sakit keras. Aku pun berkata, "Wahai Rasulullah, sesungguhnya sakitku sangat keras sebagaimana yang engkau lihat. Sedangkan aku mempunyai harta yang cukup banyak dan yang mewarisi hanyalah seorang anak perempuan. Bolehkah saya sedekahkan 2/3 dari harta itu?" Beliau menjawab, "Tidak." Saya bertanya lagi, "Bagaimana kalau separuhnya?” Beliau menjawab, "Tidak." Saya bertanya lagi, "Bagaimana kalau sepertiganya?” Beliau menjawab, "Sepertiga itu banyak (atau cukup besar). Sesungguhnya jika kamu meninggalkan ahli warismu kaya, itu lebih baik

\footnotetext{
${ }^{6}$ Mausuah al-Hadis al-Syarif al-Kutub al-Tis'ah, Shahih al-Bukhari : no. hadis 4409 dan Muslim no. 1628.
} 
daripada kamu meninggalkan mereka dalam keadaan miskin sehingga mereka terpaksa memintaminta kepada sesama manusia. Sesungguhnya apa yang kamu nafkahkan dengan maksud untuk mencari ridha Alah pasti kamu diberi pahala, termasuk apa yang dimakan oleh istrimu."Aku bertanya, "Wahai Rasulullah, apakah aku akan segera berpisah dengan kawan-kawanku?" Beliau menjawab, "Sesungguhnya engkau belum akan berpisah. Kamu masih akan menambah amal yang kamu niatkan untuk mencari ridha Allah, sehingga akan bertambah derajat dan keluhuranmu. Dan barangkali kamu akan segera meninggal setelah sebagian orang dapat mengambil manfaat darimu, sedangkan yang lain merasa dirugikan olehmu. Ya Allah, mudah-mudahan sahabat-sahabatku dapat melanjutkan hijrah mereka dan janganlah engkau mengembalikan mereka ke tempat mereka semula. Namun, yang kasihan (merugi) adalah Sa'ad bin Khaulah. Rasulullah shallallahu 'alaihi wa sallam sangat menyayangkan ia meninggal di Makkah."

Meninggalkan harta untuk keturunan di belakang dalam hadis yang dipraktekkan pada tradisi tanggung jawab Tunggu Tubang adalah tidak dalam pengertian pragmatis, melainkan lebih kepada tanggung jawab. Sepeninggal orang tua rumah dan tanah tetap harus ada demi menunjang kelanjutan ekonomi keluarga. Harta yang ada benar-benar pas peruntukkannya. Tidak dipakai untuk sesuatu yang mubazir atau dijual untuk keperluan pribadi. Orang tua telah memikirkan bahwa di masa yang akan datang kehidupan anak keturunan tidak sama dengan apa yang telah dihadapi oleh orang tua mereka. Orang tua pun tidak akan selamanya menemani dan membantu kehidupan anaknya. Jika tidak ditinggalkan harta dan tanah serta pemahaman agama dan moralitas yang baik, serta adat yang mengikat anak keturunan akan kesulitan dalam mengarungi kehidupan nantinya.

Jadis dapat ditegaskan bahwa menjaga harta pusaka yang diamanhkan sebagai salah satu tanggung jawab Tunggu Tubang dalam tradisi masyarakat Semende adalah juga bagian pengamalan sunnah Rasulullah saw atau dikenal dengan living sunnah. Tidak ada penyimpangan dari apa yang diajarkan oleh Allah swt dan Rasul-Nya. Justru melalui tradisi tanggung jawab Tunggu Tubang, masyarakat Semende telah melestarikan sunnah (living hadis).

2. Menjaga dan mengurus orang tua.

Dalam adat Semende biasanya orang tua tinggal di rumah pusaka yang ditempati oleh Tunggu Tubang. Merupakan suatu kewajiban bagi Tunggu Tubang untuk menjaga dan mengurus orang tua, melengkapi kebutuhannya, mengobati dan membawanya berobat apabila ia sakit. Ada kalanya juga di rumah Pusaka tersebut masih terdapat kakek dan nenek Tunggu Tubang. ${ }^{7}$

Rasulullah saw bersabda :

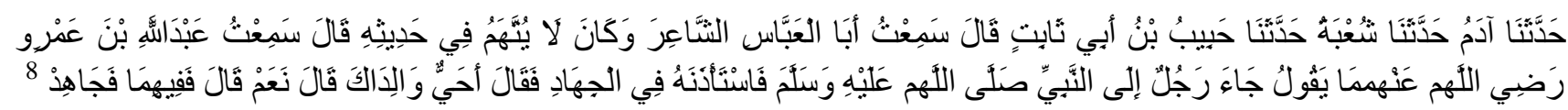

7 Dzulfikriddin, Kepemimpinan Meraje dalam Masyarakat Adat Semende dan Kesesuaiannya dengan Kepemimpinan dalam Islam, 40-41. Bandingkan dengan Thadin Amin, Pokok-Pokok Adat Semende, 9.

${ }^{8}$ Mausuah al-Hadis al-Syarif al-Kutub al-Tis'ah, Shahih Muslim, no. hadis 2782. 
Telah bercerita kepada kami Adam telah bercerita kepada kami Syu'bah telah bercerita kepada kami Habib bin Abi Tsabit berkata aku mendengar Abu Al Abbas asy Sya'ir, dia adalah orang yang tidak buruk dalam hadits-hadits yang diriwayatkannya, berkata: aku mendengar Abdullah bin 'Amru radliallahu 'anhuma berkata: "Datang seorang laki-laki kepada Nabi shalallahu 'alaihi wasallam lalu meminta izin untuk ikut berjihad. Maka beliau bertanya: "Apakah kedua orang tuamu masih hidup?" Laki-laki itu menjawab: "Ya.” Maka beliau berkata: "Kepada keduanyalah kamu berjihad (berbakti)"

Sebenarnya apabila disadari tugas menjaga dan mengurus orang tua merupakan suatu kehormatan dan kemuliaan yang diperuntukkan bagi Tunggu Tubang. Karena sesungguhnya orang tua memiliki banyak jasa dan pengorbanan untuk mendidik, mengasuh dan membesarkan anakanaknya sejak dari alam rahim hingga dewasa. Orang tua juga merupakan keramat hidup bagi anakanaknya. Aturan adat yang mengharuskan orang tua tinggal di rumah besar bersama Tunggu Tubang melahirkan banyak sekali kesempatan bagi Tunggu Tubang untuk berbakti dan berbuat baik kepada kedua orang tuanya. Karena itu Tunggu Tubang harus bisa menyadari, mensyukuri dan memanfaatkan sebaik-baiknya kesempatan berharga untuk lebih banyak berbakti kepada orang tua dibandingkan dengan saudara lainnya yang tidak diwajibkan secara adat dalam tanggung jawabnya dan tidak tinggal dalam satu atap.

Dikatakan pula bahwa dalam tanggung jawab Tunngu Tubang menjaga dan mengurus orang tua terdapat di dalamnya nilai-nilai pengamalan al-Qur'an dan sunnah Rasulullah saw. Dengan sangat jelas dan tegas baik ayat maupun hadis memerintahkan untuk berbuat baik kepada orang tua, mengurus, menjaga dan tidak menyakiti, hal ini sejalan dengan apa yang diwajibkan adat Semende dalam salah satu tanggung jawab Tunggu Tubang. Tidak ada penolakan dari pihak manapun di masyarakat Semende. Tidak ada pula Tunggu Tubang yang mengingkari tanggung jawabnya ini. Semua berjalan sesuai aturan adat dan diwarnai oleh pemahaman al-Qur'an dan hadis. Karenanya dikatakan bahwa dalam tanggung jawab Tunggu Tubang menjaga dan mengurus orang tua adalah juga bagian dari pengamalan sunnah yang hidup di masyarakat Semende atau dikenal dengan istilah living hadis.

3. Menghormati Meraje dan mematuhi perintahnya.

Meraje adalah kakak atau adik laki-laki dari ibu (Tunggu Tubang), berapapun jumlahnya. Hanya saja dalam melaksanakan tugas-tugas yang berkenaan dengan hak dan kewajiban selaku Meraje, biasanya yang tertua lebih didahulukan baru kemudian yang lebih muda sampai kepada yang 
termuda. Kecuali apabila yang tertua telah menyerahkan kepemimpinan dan pengawasannya kepada yang lebih muda untuk mengambil kebijaksanaan dan melaksanakannya. ${ }^{9}$

Sistem kekerabatan atau sistem kekeluargaan Semende bukan memakai sistem Matrilinial (garis ibu) dan tidak pula memakai sistem Patrilinial (garis bapak), melainkan suatu sistem khusus yang tidak terdapat dalam adat lain. Kekhususannya adalah bahwa seorang anak bukan hanya anak ibunya atau anak bapaknya saja, tetapi anak ibu sekaligus anak bapaknya juga, dalam pengertian memiliki tanggung jawab dan hak kepada seluruh anggota keluarganya dari sebelah ibu ataupun bapaknya, dengan pembagian tanggung jawab dan hak yang berbeda antara laki-laki dan perempuan.

Rasulullah saw bersabda :

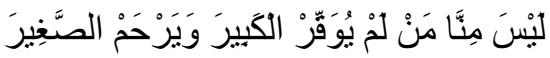

Tidaklah termasuk golonganku orang yang tidak menghormati yang lebih tua dan tidak menyayangi yang muda

Bila kepada sesama muslim saja wajib untuk berhusnudz-dzan, tentu seharusnya kepada para saudara kandung. Sudah seharusnya memperlakukan sadara kandung dengan rasa hormat. Meskipun ternyata perbedaan usia yang hanya terpaut dekat, berbeda dalam pengetahuan, wawasan dan kemampuan, akan tetapi sebagai saudara diharapkan mampu menghormati saudaranya agar hubungan tetap terjalin dengan baik.

Secara khusus terkait dengan tanggung jawab Tunggu Tubang dalam menghormati dan mematuhi Meraje maka hal ini berkaitan dengan apa saja yang menjadi hak-hak Meraje, yaitu ${ }^{10}$ :

1. Memimpin Musyawarah.

Masyarakat Semende adalah masyarakat yang mengutamakan musyawarah dalam mengambil keputusan-keputusan penting. Baik hal itu berkenaan dengan masalah keluarga, kepentingan umum masyarakat desa, ataupun yang berhubungan dengan masalah pemerintahan. Pada tata cara dan perintah untuk melakukan musyawarah ketika mengambil keputusan, Allah swt berfirman :

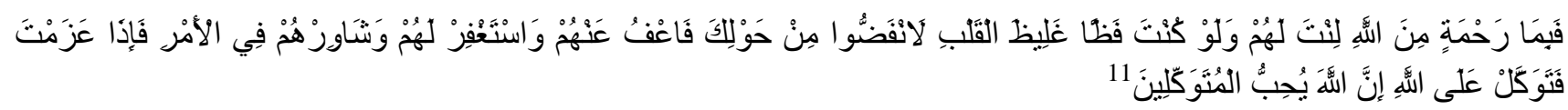

9 Dzulfikriddin, Kepemimpinan Meraje dalam Masyarakat Adat Semende dan Kesesuaiannya dengan Kepemimpinan dalam Islam, 25-27. Bandingkan dengan Soerojo Wigjodinoe, Pengantar dan Azas-Azas Hukum Adat, 20. Bandingkan juga dengan Thadin Amin, Pokok-Pokok Adat Semende, 7.

10 Dzulfikriddin, Kepemimpinan Meraje dalam Masyarakat Adat Semende dan Kesesuaiannya dengan Kepemimpinan dalam Islam, 29-33. Thadin Amin, Pokok-Pokok Adat Semende, 8.

${ }^{11}$ Q.S. al-Imran : 159. 
Maka berkat rahmat Allah engkau berlaku lemah lembut terhadap mereka. Sekiranya engkau bersikap keras dan berhati kasar tentulah mereka menjauhkan diri dari sekitarmu. Karena itu maafkanlah mereka dan mohonkanlah ampunan untuk mereka, dan bermusyawarahlah dengan mereka dalam urusan itu. Kemudian apabila engkau telah membulatkan tekad maka bertawakallah kepada Allah. Sungguh Allah mencintai orang yang bertawakal.

Perintah bermusyawarah pada ayat tersebut turun setelah peristiwa menyedihkan pada perang Uhud, ketika itu menjelang pertempuran Rasulullah saw mengumpulkan sahabat-sahabatnya untuk mencari solusi mengenai cara menghadapi musuh yang sedang dalam perjalanan dari Makkah menuju ke Madinah. Rasul saw cenderung untuk bertahan di kota Madinah, dan tidak keluar untuk menghadapi musuh yang datang dari Makkah. Sementara para sahabat Rasulullah saw terutama dari golongan muda dengan penuh semangat mendesak agar kaum muslim di bawah pimpinan Rasul saw keluar untuk menghadapi musuh. Pendapat kaum muda ini adalah pendapat mayoritas, sehingga Rasul saw menyetujuinya dan meninggalkan pendapatnya sendiri. Meskipun pada akhirnya peperangan berakhir dengan gugurnya para sahabat yang jumlahnya tidak kurang dari tujuh puluh orang. Setelah kejadian itulah Rasulullah saw memutuskan untuk menghapus musyawarah.

Konteks turunnya ayat ini, serta kondisi psikologis yang dialami Rasulullah saw dan sahabatnya perlu untuk digaris bawahi. Hal ini dimaksudkan untuk melihat bagaimana pandangan alQur'an dan hadis tentang musyawarah. Ayat seakan-akan berpesan secara khusus kepada Rasul saw, bahwa musyawarah harus tetap dipertahankan dan dilanjutkan. Walaupun terbukti pendapat yang mereka putuskan keliru. Kesalahan mayoritas lebih dapat ditoleransi dan menjadi tanggung jawab bersama, dibandingkan dengan kesalahan seseorang meskipun diakui kualitas pendapatnya sekalipun. $^{12}$

Pengamaalan al-Qur'an dan hadis yang berkaitan dengan tanggung jawab Tunggu Tubang adalah menyerahkan kepemimpinan Meraje dalam musyawarah untuk mengambil keputusan yang terbaik bagi jurai (keluarga). Begitu juga yang dilakukan oleh Dewan Meraje sebagai kumpulan Meraje dalam adat Semende senantiasa bermusyawarah dalam mengambil keputusan adat. Musyawarah dilakukan dengan cara melibatkan para Meraje saja, ada pula yang mengikutsertakan Tunggu Tubang dan bisa juga mengajak seluruh Anak Balai. 2001)467.

${ }^{12}$ M. Quraish Shihab, Wawasan al-Qur'an : Tafsir Maudhu'I atas Berbagai Persoalan Ummat (Bandung: Mizan, 
Adapun persoalan yang biasanya dimusyawarahkan ${ }^{13}$ adalah :

1. Waktu memulai mengerjakan sawah.

2. Waktu memulai menuai padi.

3. Bila hendak mencari gadis untuk bujang keluarga.

4. Bila gadis keluarga dilamar orang.

5. Bila ada pelanggaran adat atau agama, yang dilakukan oleh anggota Jurai.

6. Ketika hendak mengadakan upacara mbaji/ ziarah.

Meraje sebagai pemimpin Jurai tidak semena-mena dalam mengambil keputusan. Utamanya hal-hal penting diantaranya yang berkaitan dengan enam persoalan tersebut menjadi pembahasan dalam musyawarah. Hal ini tidak hanya sesuai dengan perintah Allah swt melainkan juga merupakan pengamalan dari hadis Rasulullah saw yang dalam istilah ilmu hadis disebut sebagai living hadis.

\section{Menetapkan Tunggu Tubang.}

Sebagai pemimpin dalam Jurai (keluarga) salah satu hak Meraje adalah menetapkan siapa yang akan menjadi Tunggu Tubang berikutnya dalam Jurai. Meskipun pada dasarnya anak perempuan tertua otomatis menjadi Tunggu Tubang, akan tetapi penetapannya tetap melalui musyawarah yang dihadiri oleh seluruh anggota Jurai yang dipimpin Meraje. Lebih-lebih lagi bila dalam keluarga itu tidak ada anak perempuan, maka musyawarah harus diadakan untuk menetapkan siapa di antara beberapa anak laki-laki yang akan menjabat sebagai Tunggu Tubang.

Rasulullah saw bersabda :

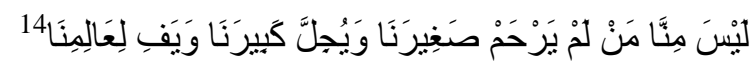

Bukanlah termasuk golongan kami, orang yang tidak menghormati orang yang lebih tua, tidak menyayangi yang muda, dan tidak mengerti hak ulama kami.

Meskipun secara khusus hadis tersebut menjelaskan tentang penghormatan kepada ulama, hakikatnya sabda Rasulullah saw tersebut mengajarkan utnuk menghormati orang yang memiliki kelebihan dalam keilmuannya. Akan halnya Meraje selain ia adalah saudara laki-laki tertua dari ibu,

13 Dzulfikriddin, Kepemimpinan Meraje dalam Masyarakat Adat Semende dan Kesesuaiannya dengan Kepemimpinan dalam Islam, 29-33. Thadin Amin, Pokok-Pokok Adat Semende, 54.

${ }^{14}$ Mausuah al-Hadis al-Syarif al-Kutub al-Tis'ah, Shahih al-Bukhariy, no. hadis 4319. 
dalam kedudukan dan ilmunya (khususnya dalam bidang adat istiadat) ia telah diberikan hak untuk mengambil tanggung jawab dan kebijakan. Karena itu apa yang dilakukan masyarakat Semende memberi penghormatan kepada Meraje adalah sunnah Rasulullah saw yang diamalkan dalam kehidupan bermasyarakat (living hadis).

\section{Menjadi Juru Bicara atau Besuare.}

Yang dimaksudkan dengan besuare atau berbicara adalah menjadi juru bicara keluarga dalam hal-hal tertentu. Hak berbicara mewakili kelompok secara umum diserahkan kepada kaum lelaki. Lelaki menemukan sifat maskulinitas dalam kemandirian, kebebasan dan kepemimpinan. Karena itulah, seorang lelaki selamanya cenderung pada kekuatan, kemampuan, peran, dan prestasi. Dalam perannya sebagai pemimpin diantaranya seorang laki-laki memiliki hak untuk menjadi wali atau juru bicara dalam pertemuan keluarga yang dihadiri oleh para lelaki dan perempuan, baik dalam forum keluarga maupun organisasi. Demikian juga yang dilakukan oleh masyarakat Semende dalam tanggung jawab Tunggu Tubang terkait hak Meraje untuk diposisikan sebagai penyampai hajat yang mewakili keluarga.

Rasulullah saw bersabda :

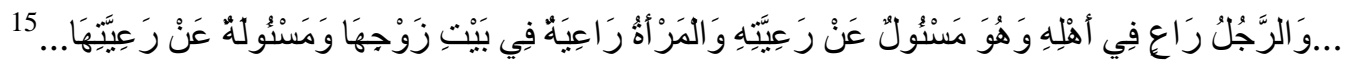

... Seorang suami adalah pemimpin dan akan dimintai pertanggung jawaban atas keluarganya. Seorang isteri adalah pemimpin di dalam urusan rumah tangga suaminya, dan akan dimintai pertanggung jawaban atas urusan rumah tangga tersebut...

Kepemimpinan dalam rumah tangga secara umum dipegang oleh kaum laki-laki suami, maka pemimpin keluarga adalah orang tua laki-laki atau laki-laki tertua. Tidak berbeda apa yang menjadi tradisi dari masyarakat Semende bahwa laki-laki tertua dalam keluarga yang disebut Meraje adalah pemimpin dalam keluarga (Jurai) yang memiliki hak kepemimpinan di antaranya besuare atau menjadi juru bicara dalam pertemuan adat atau acara keluarga lainnya. Termasuk pula hak untuk mengambil kebijakan dan keputusan. Dalam persoalan ini pun apa yang dilakukan oleh masyarakat Semende disebut sebagai pengamalan hadis atau menghidupkan sunnah dalam kehidupan sehari-hari. Karenanya dapat dikatakan bahwa living hadis ada dalam tradisi besuare yang dilakukan oleh Meraje di keluarga Semende.

${ }^{15}$ Mausuah al-Hadis al-Syarif al-Kutub al-Tis'ah, Shahih al-Bukhari : no. hadis 460. 
4. Mematuhi dan menjalankan aturan adat.

Sebuah lingkungan masyarakat di manapun berada pasti memiliki aturan yang mengatur perilaku anggota masyarakatnya. Ketaatan masyarakat terhadap aturan mencerminkan kesadaran hukum yang dimiliki oleh masyarakat. Semakin tinggi kesadaran masyarakat maka semakin rendah tingkat pelanggaran hukumnya. Sebuah aturan hukum akan ditaati dan dipatuhi oleh masyarakat apabila aturan tersebut memberikan jaminan akan hak dan kewajiban secara proporsional. Ketika seseorang merasakan suatu aturan yang melingkupinya memberikan kenyamanan maka individu tersebut akan tunduk dan patuh pada aturan hukum tersebut. Dalam masyarakat hidup aturan yang tidak tertulis, yang lebih dikenal dengan hukum adat, namun demikian meskipun aturan-aturan tersebut tidak tertulis tetapi masyarakat (adat) tetap mematuhi aturan tersebut.

Pada dasarnya hukum merupakan sebuah norma dan terbentuk akibat adanya aktivitas dan kegiatan manusia. Hukum adat lahir dari segala kebiasaan baik. Berbeda dengan tradisi yang juga berasal dari sesuatu yang kurang baik. Karena adat lahir dari kebiasaan yang baik maka hukum adat ditaati oleh masyarakat. Jika dibandingkan dengan undang-undang yang terkesan kaku dan cenderung manjadi belenggu bagi masyarakat. ${ }^{16}$

Walaupun tidak tertulis namun hukum adat mempunyai akibat hukum terhadap siapa saja yang melanggarnya. Norma-norma dan nilai-nilai yang ada di dalam hukum adat sangat dipatuhi dan dipegang teguh oleh masyarakat adat. Karena peraturan-peraturan adat biasanya bersifat tidak tertulis, tumbuh dan berkembang dalam suatu masyarakat, maka hukum adat memiliki kemampuan menyesuaikan diri dan elastis.

Adapun hadis mauquf yang dijadikan dalil adalah riwayat Abdullah bin Mas'ud :

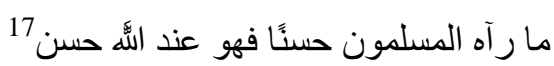

Segala hal yang dianggap oleh kaum (masyarakat) muslim sebagai sesuatu yang baik maka di sisi Allah hal itu adalah baik pula.

Kebiasaan masyarakat luas bisa dijadikan landasan dalam syariat. Seperti halnya madzhab Malikiyah yang tidak sedikit berdalil dengan kebiasaan penduduk Madinah dan menjadikannya lebih kuat dari khabar ahad. Bahkan Madzhab Hanafiah dalam berdalil dengan Istihsan menjadikan adat dan kebiasaan masyarakat lebih kuat posisi dalilnya dibandingkan dengan dalil dari redaksi ayat dan

\footnotetext{
${ }^{16}$ Muhammad Mustofa al-Zuhaily, al-Wajiz fiy al-Ushul al-Fiqh (Damaskus : Dar al-Khair, 2006), Jilid I, 265.

${ }^{17}$ Mausuah al-Hadis al-Syarif al-Kutub al-Tis'ah, Musnad Ahmad, no. hadis 6735.
} 
hadis yang berkonotasi umum. Berbeda dengan madzhab Syafi'iyah yang menempatkan urf shhih sebagai pijakan setelah empat dalil muttafaq (al-Qur'an, Sunnah, Ijma' dan Qiyas). Secara garis besar dapat disimpulkan bahwa para ulama sepakat tentang posisi urf shahih sebagai dalil syar'i. ${ }^{18}$

Tanggung jawab Tunggu Tubang yang menjadi kewajibannya adalah mematuhi dan menjalankan aturan adat. Maksudnya segala sesuatu yang berkenaan dengan adat Semende yang mencakup Rukun Semende, Adat Semende, Tungguan Semende, serta Sifat dan Lambang Tunggu Tubang harus senantiasa dimengerti dan dilaksanakan oleh Tunggu Tubang. Adapun Lambang Adat Semende tersebut ada lima, ${ }^{19}$ yaitu :

1. Pusat Pumpunan Jale.

Rumah Tunggu Tubang sebagai sentral silaturahmi dari seluruh keluarga besar menjadi tempat menggantungkan harapan dari seluruh anggota Jurai dan penjaga utama harta pusaka nenek moyang. Pusat Pumpunan Jale dimaksudkan agar sewaktu-waktu dapat menarik dan menghimpun seluruh anggota Jurai untuk berkumpul dan bersilaturahmi.

2. Kampak bukan Pahat.

Tunggu Tubang harus bersifat seperti kampak, maksudnya adalah: alat untuk bekerja. Dengan bersifat seperti kampak Tunggu Tubang harus bekerja keras untuk memberi manfaat yang sebanyakbanyaknya bagi keluarga besar, Apit Jurai dan anggota keluarga lainnya. Kampak juga melambangkan keadilan. Karena kedua sisinya yang sama-sama tajam tidak seperti pahat yang hanya tajam di satu sisi.

3. Kujur bukan Balau.

Kujur adalah satu jenis benda pusaka seperti tombak kecil. Kujur melambangkan kewibawaan, kepatuhan, kesetiaan, kejujuran dan keikhlasan.Tunggu Tubang harus memiliki sifat ini agar dihormati dan disegani orang sekampung halaman serta setia dan taat kepada ibu, bapak, mertua dan para Meraje.Tunggu Tubang harus mentaati perintah kemanapun dan kapanpun perintah itu diberikan.

\section{Guci.}

Guci merupakan tempat penyimpanan bahan makanan yang sewaktu-waktu dapat dimasak dalam jangka waktu yang relatif singkat dan mudah. Jika ada anggota keluarga atau tamu yang datang utamanya pada malam hari sehingga tidak perlu pergi ke pasar atau warung untuk membeli

${ }^{18}$ Hasan bin Muhammad bin Mahmud al-Athor, Hassiyat al-Athor 'ala Syarh Jalal al-Mahli 'ala Jami alJawami', 396.

19 Thohlon Abdul Rauf, Jagat Besemah Lebar Semende Panjang, (Palembang, Pustaka Dzu Mirrah Yayasan Nurqadim, 1989), Jilid I dan II, 211-213.Bandingkan dengan Bermawi HMS, Lambang Adat Semende dan Pancasila, (Palembang; Yayasan Pembangunan Rakyat Semende, 1989), 4-12. 
lauk-pauk guna menjamu tamu yang datang. Guci melambangkan penampilan yang anggun, bersih, rapi, indah, sabar dan mampu menyimpan rahasia.

5. Pauk Penuh Air bukan Pauk Kering.

Pauk adalah kolam atau tebat untuk tempat berternak ikan. Apabila airnya penuh akan terlihat indah dan menarik, memikat hati untuk mandi dan bermain-main. Selain itu Pauk yang penuh airnya melambangkan kedalaman sehingga orang tidak tahu apa isinya. Ketenangan dan kesabaran sehingga tidak mudah mengeluh. Tunggu Tubang harus bersifat seperti pauk penuh berisi air untuk dapat menghayati dan bersifat dengan apa-apa yang dilambangkan.

Tidak ada yang bertentangan dengan dalil al-Qur'an ataupun hadis. Semua yang dijalankan dalam tradisi masyarakat Semende adalah sesuai dengan apa yang diperintahkan oleh Allah swt melalui al-Qur'an dan juga merupakan pengamalan dari sunnah Rasulullah saw. Karenanya bisa dikatakan bahwa dalam tradisi masyarakat Semende selain merupakan penerapan nilai-nilai alQur'an juga merupakan menghidupkan sunnah Rasulullah saw dalam keseharian masyarakat atau yang lebih dikenal sebagai living hadis.

Secara keseluruhan dapat disimpulkan bahwa dalam tanggung jawab Tunggu Tubang yang meliputi empat hal utama yaitu, pertama : menjaga dan mengurus harta pusaka, kedua : menjaga dan mengurus orang tua, ketiga : menghormati Meraje dan mematuhi perintahnya dan keempat : mematuhi dan menjalankan aturan adat terdapat pengamalan nilai-nilai al-Qur'an karena apa yang dilaksanakan dalam tradisi ini sesungguhnya tidak menyalahi bahkan sesuai dengan apa yang diperintahkan oleh Allah swt. Selain itu tentunya empat tanggung jawab Tunngu Tubang ini adalah juga tradisi yang disunnahkan oleh Rasulullah saw, karena apa yang menjadi tradisi masyarakat Semende ini adalah merupakan Sunnah Rasulullah saw.

\section{B. Hak Tunggu Tubang.}

Ada dua hak Tunggu Tubang yang terdapat dalam adat $S_{e m e n d e}{ }^{20}$, yaitu :

1. Menikmati harta pusaka.

Tugas Tunggu Tubang adalah menjaga dan mengurus harta pusaka Jurai yang minimal terdiri dari sebuah rumah dan sebidang sawah. Ia harus menjaga rumah itu agar jangan rusak, mengolah dan mengerjakan sawah agar menghasilkan padi yang berlimpah untuk kehidupan keluarga. Tunggu Tubang diberi hak untuk menempati rumah pusaka sebagai kediaman keluarganya serta menikmati hasil sawah untuk kehidupan mereka sehari-hari. Walaupun Tunggu Tubang diberi hak untuk

20 Dzulfikriddin, Kepemimpinan Meraje dalam Masyarakat Adat Semende dan Kesesuaiannya dengan Kepemimpinan dalam Islam, 43-45. Thohlon Abdul Rauf, Jagat Besemah Lebar Semende Panjang, Jilid I dan II, 213. Bandingkan juga dengan Soerojo Wigjodinoe, Pengantar dan Azas-Azas Hukum Adat, 23. 
menikmati harta pusaka, sekali-kali dia tidak berhak untuk menjual atau mengadaikannya. Hal itu disebabkan karena harta pusaka tersebut adalah milik bersama seluruh anggota Jurai (keluarga) hanya saja dikuasakan menurut adat kepada Tunggu Tuabng untuk menjaga dan mengurusnya.

Menjaga harta pusaka kemudian mengelola dan mengembangkannya merupakan bagian dari amal sholeh. Selain berperan sebagai pengemban amanah keluarga, mengelola harta pusaka apabila bermanfaat bagi pengembangan harta dan mencukupi kebutuhan bersama juga tentu saja bermanfaat bagi si pengelola. Rasulullah saw bersabda :

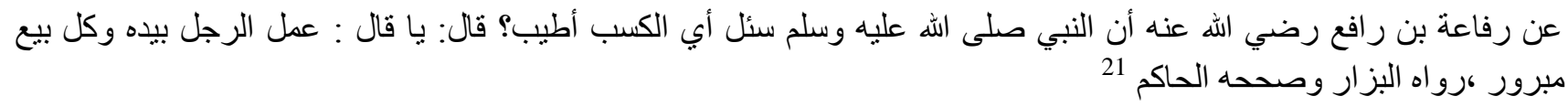

Dari Rifa'ah bin Rafi' radhiyallahu 'anhu, bahwa Nabi shallallahu 'alaihi wasallam ditanya : "Apakah pekerjaan yang paling baik / afdhol?" (kemudian) Ia (Rasulullah saw) menjawab : "Pekerjaan seorang laki-laki dengan tangannya sendiri (hasil jerih payah sendiri), dan setiap jual beli yang mabrur.

Hadis ini sahih dengan banyaknya jalur periwayatannya. Ibnu Hajar al-'Asqalani berkata bahwa hadis diiriwayatkan oleh al-Bazzar dan dishahihkan oleh al-Hakim. ${ }^{22}$ Rasulullah saw bersabda:

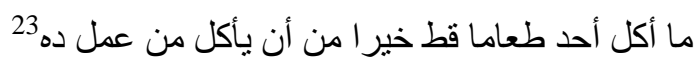

Tidak ada satu makanpun yang lebih baik dari pada apa yang dimakan oleh seseorang dari hasil kerjanya sendiri.

Para ulama berbeda pendapat tentang pekerjaan duniawi yang paling utama. Sebagian mereka mengatakan yang utama adalah bercocok tanam (bertani), sebagian yang lain mengatakan perdagangan, dan sebagian yang lain mengatakan bahwa yang utama adalah pekerjaan seseorang dengan tangan sendiri berupa produksi maupun keahlian yang lain. ${ }^{24}$ Sesuai dengan pokok pembahasan sunnah Rasulullah saw yang dilaksanakan dalam tradisi hak Tunggu Tubang mengelola dan menikmati harta pusaka disimpulkan bahwa sesunguhnya pekerjaan yang paling utama adalah pekerjaan yang sesuai dengan kondisi seseorang per individu. Bisa disesuaikan dengan kemampuan dan juga minat, namun yang terpenting dari melakukan pekerjaan adalah ketulusan dan jujur serta amanah.

\footnotetext{
${ }^{21}$ Mausuah al-Hadis al-Syarif al-Kutub al-Tis'ah, Shahih al-Bukhariy, no. hadis 4532 .

${ }^{22}$ Hasan bin Muhammad bin Mahmud al-Athor, Hassiyat al-Athor 'ala Syarh Jalal al-Mahli 'ala Jami alJawami', 397.

${ }^{23}$ Q.S. al-Mulk : 15.
} 
Disunnahkan untuk bekerja walaupun telah berkecukupan, sebagaimana dibolehkan mencari pekerjaan yang halal untuk menambah kekayaan, kedudukan, kemewahan, kesenangan dan kelapangan terhadap anggota keluarganya yang disertai dengan selamatnya agama, kehormatan, harga diri dan lepasnya tanggung jawab. Wajib bagi seseorang yang tidak memiliki bahan makanan untuk berkerja guna memenuhi kebutuhan dirinya dan untuk orang-orang yang dinafkahinya. Dalam etika menafkahi dijelaskan bahwa harus mendahulukan bekerja untuk memenuhi kebutuhan keluarganya. Tidak adanya pembatasan terhadap jenis pekerjaan tertentu, hanya saja ketika pekerjaan tersebut tidak melanggar aturan Allah swt dan Rasul-Nya dan tidak pula mengambil ataupun merampas hak manusia lain, maka pekerjaan tersebut tetap dihalalkan dan dianjurkan untuk dilaksanakan. Rasulullah saw bersabda :

$$
\text { كفى بالمرء إثما أن يضيع من يقوت. رو اه مسلم25 - م }
$$

Cukuplah seseorang dikatakan berdosa, ketika menelantarkan siapa yang menjadi tanggungannya (tidak memberinya nafkah).

Menjaga, mengelola dan menikmati harta pusaka adalah termasuk jenis pekerjaan mulia. Karena selain tidak bermaksiat kepada Allah swt, pekerjaan tersebut mengandung kemaslahatan bagi orang banyak. Menjaga, mengelola dan menikmati harta pusaka memiliki banyak makna baik dalam konteks menegakkan dan melestarikan tradisi turun-temurun di lingkungan masyarakat tempat tinggal juga mengupayakan pengelolaan dan pengembangan harta keluarga, memegang amanah orang tua dan kehormatan keluarga serta memberikan manfaat bagi orang lain dari hasil jerih payahnya. Untuk itu tradisi masyarakat Semende yang berhubungan dengan hak Tunggu Tubang menjaga dan mengelola harta pusaka selanjutnya menikmati hasil dari usahanya bisa dikatakan sebagai tradisi yang baik yang juga melambangkan pengamalan tradisi (sunnah ) Rasulullah saw atau yang dikenal dengan sebutan living hadis.

2. Menjadi tempat kembali para anggota Jurai.

Rumah Pusaka yang diamanatkan kepada Tunggu Tubang untuk menjaga dan menunggunya. Rumah Tunggu Tubang tidak boleh kosong dan ditinggalkan terlalu lama, karena sewaktu-waktu atau dalam keadaan tertentu ada anggota Jurai akan datang untuk sesuatu urusan. Adakalanya pula rumah pusaka tersebut dijadikan tempat untuk sesuatu keperluan keluarga, seperti hajatan pernikahan, musibah kematian, ziarah ke makam nenek moyang. Karena itu persediaan padi di lumbung sawah Tunggu Tubang harus selalu ada agar dapat menjamu para anggota Jurai yang

${ }^{24}$ Hasan bin Muhammad bin Mahmud al-Athor, Hassiyat al-Athor 'ala Syarh Jalal al-Mahli 'ala Jami alJawami', 399. 
datang. Padi di sawah Tunggu Tubang harus disimpan dalam lumbung serta tidak boleh dijual semuanya, kecuali sekedar untuk memenuhi keperluan yang sangat mendesak.

Rumah adalah suatu nikmat dari Allah swt yang terkadang, bahkan sering dilupakan oleh manusia. Padahal dengan adanya rumah, manusia bisa mendapatkan banyak sekali kemudahan dan kesenangan dalam hidup. Allah swt berfirman :

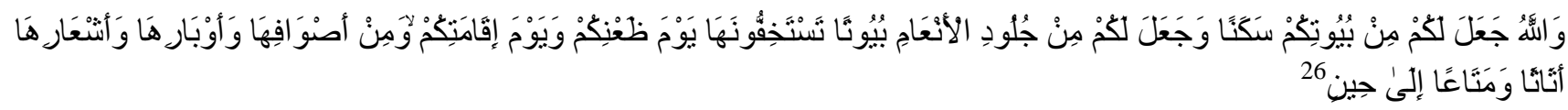

Dan Allah menjadikan bagimu rumah-rumahmu sebagai tempat tinggal dan Dia menjadikan bagi kamu rumah-rumah (kemah-kemah) dari kulit binatang ternak yang kamu merasa ringan (membawa) nya di waktu kamu berjalan dan waktu kamu bermukim dan (dijadikan-Nya pula) dari bulu domba, bulu onta dan bulu kambing, alat-alat rumah tangga dan perhiasan (yang kamu pakai) sampai waktu

(tertentu).

Dalam suatu riwayat dikemukakan bahwa ketika seorang Arab bertanya kepada Rasulullah saw tentang Allah swt maka Rasul saw membacakan ayat tersebut. Menurut Muhammad Ali al-Shabuni,

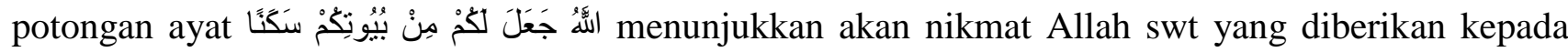
hamba-Nya. Nikmat itu berupa rumah yang dijadikan oleh Allah swt dari batu dan batu bata agar manusia tinggal di dalamnya ketika bermukim di negara-negara mereka. ${ }^{27}$. Ayat tersebut juga mengandung makna bahwa Allah swt menciptakan bagi manusia bahan-bahan untuk dijadikan rumah, serta mengilhami mereka cara pembuatannya. Ilham membuat rumah merupakan tangga pertama bagi bangunnya peradaban umat manusia sekaligus merupakan upaya paling dini dalam membentengi diri manusia guna memelihara kelanjutan hidup pribadi, bahkan jenisnya. ${ }^{28}$

Pada ayat selanjutnya Allah swt tidak lupa mengingatkan kepada seluruh ummat manusia jika sudah mendapatkan nikmat dari Allah swt masih saja berpaling dari agama Allah swt dan malah memilih jalan yang sesat, maka Allah swt akan menetapkan pembalasan-Nya terhadap mereka yang sebenarnya mengetahui betapa besar nikmat Allah swt kepada mereka, tetapi malah mengingkari nikmat-nikmat tersebut. $^{29}$

\footnotetext{
${ }^{25}$ Mausuah al-Hadis al-Syarif al-Kutub al-Tis'ah, Shahih Muslim, no. hadis 2145.

${ }^{26}$ Q.S. al-Nahl : (80).

${ }^{27}$ M.Ali As-shabuni, Shafwah Al-Tafasir (Beirut: Dar al-Fikr, 2001), 127

${ }^{28}$ Quraish Shihab, Tafsir Al-Misbah,(Jakarta: Lentera Hati, 2007) 307

${ }^{29}$ Lihat Q.S. al-Nahl : 81-83
} 
Nikmat baru terasa ketika lenyap. Ketika hilang dan rusak sebuah rumah tempat tinggal barulah merasakan betapa besar nikmat atas rumah tersebut. Terkadang, Allah swt menghukum dan menyiksa suatu kaum dengan cara menghancurkan rumah-rumah mereka. Sebagaimana Allah swt menghukum Bani Nadhir dengan menghancurkan rumah-rumah mereka. Firman Allah swt :

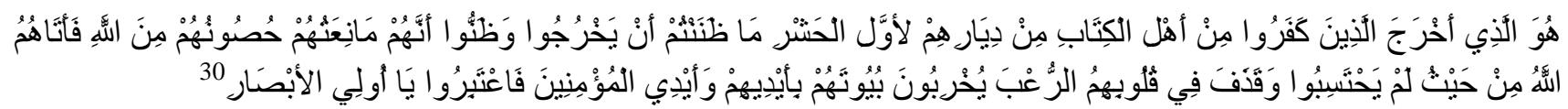

Dia-lah yang mengeluarkan orang-orang kafir di antara Ahli Kitab dari kampung halamannya pada saat pengusiran yang pertama. Kamu tidak menyangka, bahwa mereka akan keluar dan mereka pun yakin, benteng-benteng mereka akan dapat mempertahankan mereka dari (siksaan) Allah; maka Allah mendatangkan (siksaan) kepada mereka dari arah yang tidak mereka sangka-sangka. Dan Allah menanamkan rasa takut ke dalam hati mereka; sehingga mereka memusnahkan rumah-rumah mereka dengan tangannya sendiri dan tangan orang-orang mukmin. Maka ambillah (kejadian itu) untuk menjadi pelajaran, wahai orang-orang yang mempunyai pandangan.

Penghancuran rumah tempat tinggal adalah salah satu bentuk azab dari Allah swt. Karena itu merawat rumah dan menjaganya adalah bentuk dari rasa syukur yang akan menjauhkan dari murka Allah swt. ${ }^{31}$ Rumah adalah kata yang mempunyai banyak makna. Ada yang mengilustrasikan bahwa rumahku istanaku. Ada juga yang mengatakan rumah adalah tempat tinggal, tempat dibesarkan. Namun rumah hakikatnya lebih daripada itu.

Setelah dirasa cukup untuk bisa hidup mandiri demi mencari ilmu, mencari nafkah, peningkatan pengetahuan dan kualitas diri atau karena menikah dan memiliki keluarga baru, maka terpaksa harus meninggalkan rumah. Meskipun belum tentu setiap saat bisa kembali pulang, namun apabila berkesempatan pulang ke rumah yang masih terawat dan disambut oleh keluarga yang tinggal dan bertanggung jawab untuk mengurus dan menjaga rumah, tentu akan lebih nikmat rasanya daripada pulang ke rumah kosong yang tidak terawat karena tidak ada yang menghuninya. Bahkan yang lebih sedih daripada itu ketika keinginan dan kesempatan untuk pulang ada, namun sayangnya rumah tempat kembali sudah tidak ada lagi. Rumah terpaksa dijual tidak hanya karena tidak ada yang bisa mengurus dan menjaga rumah namun lebih disebabkan kurangnya rasa pemilikan dan tanggung jawab moril untuk menjaga dan merawat peninggalan orang tua.

Tidak salah bahkan dikatakan sebagai satu pengamalan al-Quran dan sunnah (tradisi) Rasulullah saw serta tradisi masyarakat, jika penjagaaan, pengelolaan dan perawatan rumah diamanahkan kepada salah seorang anggota keluarga. Hal ini sebagaimana ayat dan hadis yang telah

\footnotetext{
${ }^{30}$ Q.S. al-Hasyr : 2.

${ }^{31}$ Lihat Q.S.Ibrahin : 7.
} 
dijelaskan secara panjang lebar di halaman sebelumnya. Dengan adanya tradisi Tunggu Tubang dalam tanggung jawab dan haknya mengurus, memelihara dan mengelola harta pusaka keluarga maka akan ada orang yang bertanggung jawab secara khusus untuk memelihara, menjaga dan mengelola harta pusaka termasuk rumah. Karena itu fungsi rumah sebagai tempat kembali semua anggota keluarga akan tetap ada dan lestari. Kenangan masa kecil, ketika tumbuh dan berkembang bersama keluarga akan tetap terus terjaga. Masing-masing anggota keluarga akan bisa saling mengenal dan mengetahui hubungan persaudaraan yang terjalin di antara mereka, disebabkan oleh pulang dalam satu atap, bisa saling melihat dan berjabat tangan atau paling tidak bisa melihat dari foto keluarga atau silsilah keluarga yang dipajang di dinding rumah.

\section{Kesimpulan.}

Apabila mengkaji hadis Rasulullah saw tentang tanggung jawab wanita dalam keluarga maka ditemukan dua buah titik penekanan dalam konteks permasalahn ini. Pertama bahwa wanita memiliki kedudukan yang sama dengan laki-laki. Kedua terkait dengan kesamaannya dalam kedudukan maka antara laki-laki dan perempuan memiliki tanggung jawab yang sama di dalam kehidupan, meskipun secara khusus dijelaskan perbedaan dalam tanggung jawabnya.

Dalam tanggung jawab mengurus dan menjaga rumah serta mengelola keuangan sebagaimana yang dijelaskan di dalam hadis adalah merupakan tanggung jawab wanita. Karena itu tidak salah apa yang termasuk dalam hak dan tanggung jawab Tunggu Tubang dalam tradisi masyarakat Semende. Bahkan bisa dikatakan justru apa yang menjadi tradisi masyarakat Semende adalah juga sunnah (tradisi) Rasulullah saw yang diajarkan melalui ayat dan hadis.

Meskipun dalam pelaksanaannya tidak persis sama apa yang disunnahkan oleh Rasulullah saw dengan apa yang berlaku di masyarakat. Hal ini wajar karena memang bersama dengan perubahan zaman dan meningkatnya kebutuhan serta perbedaan lokasi, telah terjadi change and contiunity dalam artian ada yang mengalami perubahan namun ada pula yang tetap berlanjut dari masa ke masa dan dari satu tempat ke tempat lain. Yang lebih penting di bailk perkembangan zaman dan perubahan masa tetap bisa dikatakan bahwa dalam tradisi masyarakat Semende khususnya pada hak dan tanggung jawab Tunggu Tubang tetap ada sunnah Rasulullah saw yang dipertahankan atau lebih dikenal dengan istilah living hadis.

\section{Daftar Pustaka}


Al-Bukhariy, Abu Abd Allah Muhammad ibn Ismail ibn Ibrahim ibn al-Mughirahibn Bardizbah alBukhariy, Beirut: Dar al-Kutub al-Ilmiyyah, [t.th.], al-Jami' al-Shahih al-Musnad alMukhtashar $m$ in Hadis Rasul Allah Shalla alaihi wa Salam.

Al-Husaini, Syekh Muhammad, Jakarta: Darul Falah, 2006, Syarah Riyadhus Shalihin.

Al-Shabuni, M.Ali, Beirut: Dar al-Fikr, 2001, Shafwah Al-Tafasir.

Bermawi HMS, Palembang; Yayasan Pembangunan Rakyat Semende, 1989, Lambang Adat Semende dan Pancasila.

Dzulfikriddin, Palembang : Pustaka Auliya, 2001 Kepemimpinan Meraje dalam Masyarakat Adat Semende dan Kesesuaiannya dengan Kepemimpinan dalam Islam.

Muhammad Mustofa al-Zuhaily, Damaskus : Dar al-Khair, 2006, Jilid I, al-Wajiz fiy al-Ushul alFiqh.

Mausuah al-Hadis al-Syarif al-Kutub al-Tis'ah. https://portal-studiislam.blogspot.co.id/2015/07/mausuah-al-hadits-al-syarif.html.

Shihab, Quraish, Wawasan al-Qur'an : Tafsir Maudhu'I atas Berbagai Persoalan Ummat Bandung: Mizan, 2001. Jakarta: Lentera Hati, 2007, Tafsir Al-Misbah.

Syaltut, Mahmud, Jakarta : Gunng Agung, 1998, Akidah dan Syari'ah Islam, diterjemahkan oleh Fachruddin HS.

Thohlon Abdul Rauf, Palembang, Pustaka Dzu Mirrah Yayasan Nurqadim, 1989), Jilid I dan II, Jagat Besemah Lebar Semende Panjang.

Wigjodinoe, Soerojo, Jakarta: Gunung Agung, 2000Pengantar dan Azas-Azas Hukum Adat. 